\title{
A comparative study of the impact of deficit irrigation on cucumber yields planted in a greenhouse and an open field in an arid environment
}

\author{
A. M. Al-Omran, I. Louki \& A. A. Aly \\ Department of Soil Sciences, Food Sciences and Agriculture, \\ King Saud University, Saudi Arabia
}

\begin{abstract}
In this study, a deficit irrigation program was investigated for its impact on cucumber crop yield (Cucumbis sativus L.) planted in an open field and a greenhouse using a drip irrigation system during 2008-2011 growing seasons. The irrigation treatments were four levels of ETc $(40,60,80$ and 100\%) in addition to the traditional practice of local farmers. At 60 and $80 \%$ ETc treatments, the deficits of irrigation were tested at different growth stages (development, middle and late stages of growth) for a total of 12 treatments in each experiment; furthermore, three replicates for each treatments were carried out. The data showed that the cucumber could tolerate a shortage of water during the middle season growth stage for both the greenhouse and the open field, and the crop response factor (Ky) values ranged between $0.57-0.76$ and $0.96-1.02$ for the greenhouse and the open field respectively. The amount of water used in $100 \%$ ETc was much lower than that of the traditional drip irrigation used by farmers, moreover the crop water productivity (CWP) values increased when the water amount decreased. The results also indicated that the highest values for CWP were found in the most stressed treatments of $40 \%$ ETc, and on the other hand the overall productivity decreased.
\end{abstract}

Keywords: deficit irrigation, crop response factor, water use efficiency, drip irrigation. 


\section{Introduction}

The ecosystem of the arid regions of Saudi Arabia is impoverished by scarcity of water resources and of predominance of sandy soil, which consists more than $45 \%$ of the cultivated soils (Bashour et al. [1]). Sandy soils are particularly critical for water management due to their low water-holding capacity, high infiltration rate and low organic matter, which may induce low water use efficiency (Al-Omran et al. [2]). The water shortage and increasing demand for water in agriculture and other sectors compel the need to adoption of irrigation strategies in Saudi Arabia. This may allow saving irrigation water for agricultural sector (Al-Harbi et al. [3], Al-Omran et al. [4]). An approach to attain the objective of saving water and increasing water use efficiency (WUE) is through using deficit irrigation program (DI) in which crops are deliberately allowed some degree of deficit irrigation through the whole growth stage or at certain stages of the growth (Topcu et al. [5], Patanè and Cosentino [6], Kirda et al. [7]). Deficit irrigation has been extensively studied on several crops (Sepaskhah and Akbari [8], Kirda et al. [7], Pereira et al. [9]) and was recommended for arid and semiarid regions (Kirda et al. [7]). Zegbe-Dominguez et al. [10]) studied DI on tomato and found that the dry mass yield did not decrease under DI compared with full irrigation. Moreover DI can save up to $50 \%$ of irrigation water and increased WUE by $200 \%$, with satisfactory yield. The adoption of deficit irrigation requires the knowledge of crop evapotranspiration (ETc), crop response to water deficit, critical stages of growth under water deficit and economic impacts of yield reduction (Pereira et al. [9]). Agele et al. [11] concluded that seasonal crop ET values were greater during reproduction growth stage of the crop. Amer et al. [12] concluded that cucumber yield significantly decreased in a linear relationship with increasing water deficit. However, no significant change was observed when water was applied above $100 \%$ ETc. Mao et al. [13] studied the effect of deficit irrigation on yield and water use of grown cucumber in China and reported that the WUE decreased when increasing the irrigation water applied from stem fruiting to the end of the growth stages. However, the WUE increased with the increase of irrigation water from cucumber fruit setting to first fruit repining. The work on yield response factor (Ky) to water for many crops have been documented in the literature (Kirda [14], Moutonnet [15]) where crops has a value of Ky lower than 1 can tolerate the water deficit. On the contrary, crops showing a Ky greater than one show a yield decrease more than proportional to the applied ET decrease, which means that the crop might not tolerate any irrigation deficit. Ayas and Demirta [16] reported that Ky value for cucumber grown in Turkey ranged between (0.196-1.31) depend of the water stress growth stage, while Amer et al. [12] concluded that these values ranged between 0.71-0.85 in field experiment in Egypt. The value of Ky for green bean was 1.23, while the values for Safflower and eggplant were 0.97 and 1.37, respectively (Lovelli et al. [17]). The deficit irrigation strategy has received very little attention in agricultural sector in Saudi Arabia; therefore, the objectives of this study were: i) determine the cucumber water requirement under drip irrigation. ii) Compare and study the effect of deficit irrigation at different stages of cucumber growth on yield and water use efficiency on open field and greenhouse. 


\section{Materials and methods}

Greenhouse and field experiments were carried out at the complex at Almohous Farm, $120 \mathrm{~km}$ northwest of Riyadh, Saudi Arabia (altitude: $722 \mathrm{~m}$ above sea level, latitude: $25^{\circ} 17^{\prime} 40^{\prime \prime} \mathrm{N}$ and longitude: $45^{\circ} 52^{\prime} 55^{\prime \prime} \mathrm{E}$ ), between February 2008 and April 2011, and a total of 12 experiments were designed. Selected properties of the soil and irrigation water were determined by standard procedure (Page et al. [18]). The soil electrical conductivity, $\mathrm{pH}, \mathrm{CaCO} 3$, sand $\%$, and clay $\%$ were $3.6 \mathrm{dS} / \mathrm{m}, 7.9 \%, 18 \%, 84 \%$, and $10 \%$, respectively. The irrigation water chemical characteristics were determined; the $\mathrm{ECW}$ was $1.43 \mathrm{dS} / \mathrm{m}$, the sodium adsorption ratio SAR was 4.1, and the classification of water was (C2-S1) according to Richards [19]. The layout of the experiment was completely randomized design with four replicates. Irrigation treatments consist of four level of ETc (40, 60, 80, and $100 \%$ ) in addition to traditional practice by farmers. At 60 and $80 \%$ treatments, deficits irrigation tested at different growth stages (development, mid., and late stages of the growth) for a total of 13 treatments at each experiment as shown in Table 1. The cultivar of "Bazz" of cucumber (Cucumbis sativus L.) was used for the experiments. The main line is $63 \mathrm{~mm}$ in diameter. The sub-main lines tubing is $16 \mathrm{~mm}$ in diameter, the length of each line is $17 \mathrm{~m}$ with emitters built at $0.5 \mathrm{~m}$ spacing with distance between rows of $1 \mathrm{~m}$. Furthermore, water meters were installed for measuring the exact amount of water applied for each treatment (Figure 1). Irrigation scheduling methods based on pan evaporation are widely used at different ETc percentage due to its availability and easy to use (Kirda et al. [7], Simsek et al. [20]).

Crop evapotranspiration (ETc) calculated from the following equation:

$$
\mathrm{ETc}=\mathrm{Eo}^{*} \mathrm{Kp} * \mathrm{Kc}
$$

where ETc is the maximum daily ET in mm; Eo is the evaporation from class A pan in $\mathrm{mm}$; $\mathrm{Kp}$ is the pan coefficient, calculated according to Allen et al. [21], and ranged from $(0.70-0.88) ; \mathrm{Kc}$ is the crop coefficient, ranging between $(0.40-1.26)$ for different stages of the growth.

The gross water requirement (GWR) was calculated by the following equation (Cuenca, 1989):

$$
\begin{gathered}
\mathrm{GWR}=\mathrm{ETc} /(1-\mathrm{LR}) \\
\mathrm{GWR}=\mathrm{KcEoKp} /(1-\mathrm{LR}) \text { Effirr }
\end{gathered}
$$

where: GWR is the gross water requirement in $\mathrm{mm} /$ day, Effirr is the irrigation efficiency and LR is the percentage of leaching requirement.

Water use efficiency or crop water productivity as reviewed by Molden [22] is generally defined as the ratio crop yield $(\mathrm{Kg})$ to volume of water applied $\left(\mathrm{m}^{3}\right)$ to produce the yield:

$$
\text { WUE }=\text { Yield/ water applied }
$$


Table 1: Irrigation treatments combinations for each run of the experiment.

\begin{tabular}{|c|c|c|c|c|c|}
\hline Treatment & $\begin{array}{l}\text { Initial } \\
\text { St. }{ }^{1}\end{array}$ & $\begin{array}{l}\text { Develop. } \\
\text { St. }\end{array}$ & $\begin{array}{l}\text { Mid. } \\
\text { St. }\end{array}$ & $\begin{array}{l}\text { Late. } \\
\text { St. }\end{array}$ & Description \\
\hline $\mathrm{T}_{1}-100$ & $1^{*}$ & 1 & 1 & 1 & $\begin{array}{l}\text { Full irrigation during the season } \\
\left(100 \% \text { of } E T_{m}\right) \text {. }\end{array}$ \\
\hline $\mathrm{T}_{2}-80-0$ & 1 & 1 & 1 & 1 & $\begin{array}{l}80 \% \text { of } \mathrm{ET}_{\mathrm{m}} \text { irrigation during the } \\
\text { season has been given. }\end{array}$ \\
\hline $\mathrm{T}_{3}-80-1$ & $0^{* *}$ & 1 & 1 & 1 & $\begin{array}{l}\text { A full irrigation up to the end of } 1^{\text {st }} \\
\text { stage, then } 80 \% \text { of } \mathrm{ET}_{\mathrm{m}} \text { for the other } \\
\text { stages. }\end{array}$ \\
\hline $\mathrm{T}_{4}-80-2$ & 1 & 0 & 1 & 1 & $\begin{array}{l}\text { A full irrigation at the development } \\
\text { stage, then } 80 \% \text { of } \mathrm{ET}_{\mathrm{m}} \text { restoration } \\
\text { for the other stages. }\end{array}$ \\
\hline $\mathrm{T}_{5}-80-3$ & 1 & 1 & 0 & 1 & $\begin{array}{l}\text { A full irrigation at the mid stage, } \\
\text { then } 80 \% \text { of } E T_{m} \text { restoration for the } \\
\text { other stages. }\end{array}$ \\
\hline $\mathrm{T}_{6}-80-4$ & 1 & 1 & 1 & 0 & $\begin{array}{l}\text { A full irrigation at the late stage, } \\
\text { then } 80 \% \text { of } E T_{m} \text { restoration for the } \\
\text { other stages. }\end{array}$ \\
\hline $\mathrm{T}_{7}-60-0$ & 1 & 1 & 1 & 1 & $\begin{array}{l}60 \% \text { of } \mathrm{ET}_{\mathrm{m}} \text { irrigation during the } \\
\text { season. }\end{array}$ \\
\hline $\mathrm{T}_{8}-60-1$ & 0 & 1 & 1 & 1 & $\begin{array}{l}\text { A full irrigation up to the end of the } \\
1^{\text {st }} \text { stage, then } 60 \% \text { of } \mathrm{ET}_{\mathrm{m}} \text { for the } \\
\text { other stages. }\end{array}$ \\
\hline Т9-60-2 & 1 & 0 & 1 & 1 & $\begin{array}{l}\text { A full irrigation at the development } \\
\text { stage, then } 60 \% \text { of } \mathrm{ET}_{\mathrm{m}} \text { restoration } \\
\text { for the remaining stages. }\end{array}$ \\
\hline $\mathrm{T}_{10-60-3}$ & 1 & 1 & 0 & 1 & $\begin{array}{l}\text { A full irrigation at the mid stage, } \\
\text { then } 60 \% \text { of } E T_{m} \text { restoration for the } \\
\text { other stages. }\end{array}$ \\
\hline $\mathrm{T}_{11-60-4}$ & 1 & 1 & 1 & 0 & $\begin{array}{l}\text { A full irrigation at the late stage, } \\
\text { then } 60 \% \text { of } E T_{m} \text { restoration for the } \\
\text { other stages. }\end{array}$ \\
\hline $\mathrm{T}_{12-40}$ & 1 & 1 & 1 & 1 & $\begin{array}{l}40 \% \text { of } \mathrm{ET}_{\mathrm{m}} \text { irrigation during the } \\
\text { season has been given. }\end{array}$ \\
\hline T13-Trad. & 1 & 1 & 1 & 1 & $\begin{array}{l}\text { The traditional drip irrigation in } \\
\text { greenhouse. The farmer does not } \\
\text { depend at scientific methods to } \\
\text { calculate the amount of applied } \\
\text { water and adds more than the } \\
\text { required water (more than } E T_{m} \text { ). }\end{array}$ \\
\hline
\end{tabular}

$*=$ The growth stage took same amount of applied water as mentioned on the treatment.

$* *=$ The growth stage took a $100 \%$ level of ET. 
The relationship between crop yield and water application is called water production function (WPF). The WPF becomes curvilinear as more of applied water goes to drainage or loss. A useful way to express the water production function is on a relative basis, where actual yield $(\mathrm{Ya})$ is divided by maximum yield $(\mathrm{Ym})$ and actual evapotranspiration (ETa) is divided by crop evapotranspiration $(\mathrm{ETc})$. The relationship between evapotranspiration deficit $(1-(\mathrm{ETa} / \mathrm{ETc}))$ and yield depression $(1-(\mathrm{Ya} / \mathrm{Ym}))$ is always linear (Doorenbos and Kassam [23]), the slope called yield response factor of the crop (ky). This relationship is expressed by the following equation:

$$
(1-(\mathrm{Ya} / \mathrm{Ym}))=\mathrm{Ky}(1-(\mathrm{ETa} / \mathrm{ETm}))
$$

\section{Results and discussion}

\subsection{Yield and water productivity}

\subsubsection{Open field}

The results found that the highest value of CWP was at the highest stressed treatment $\left(T_{12}\right)$ which recorded $12.7 \mathrm{~kg} \mathrm{~m}^{-3}$. Moreover, decreasing irrigation water to level of $80 \%$ of ETc did not affect the growth and yield (table 2). An attempt was made to establish a relationship between water consumed and yield (Figure 1). According to the mathematical analysis of the crop water production function (WPF), the predicted maximum yields were 7.58 and $8.96 \mathrm{~kg} / \mathrm{m}^{2}$ and the corresponding predicated applied water of 1290 and $980 \mathrm{~mm}$ for summer and fall respectively (Table 3 ). These results were in agreement with those reported by Al-Harbi et al. [3] and Zhang and Oweis [24]. However, Mao et al. [13] reported a polynomial relationship between ET and yield. The study also concluded that, the treatment $\mathrm{T}_{1}-100$ had the highest yield; however, treatments $\mathrm{T}_{2}, 3,4,5,6_{-}-80$, and also $T_{12}-40$ gave fairly good marketable yield while economically saving water, fertilizers, and pesticide. The result indicated that the water productivity (WP) increased with decreasing the amount of applied water; the increased values were from 9.9 to $12.7 \mathrm{~kg} \mathrm{~m}^{-3}$ for $\mathrm{T}_{1}-100$ and $\mathrm{T}_{12}-40$ respectively. On the other hand, the WP of the traditional irrigation treatment recorded lowest value $\left(3.7 \mathrm{kgm}^{-3}\right)$. It was evident that over irrigation as of traditional method lead to lower water productivity, however lack of irrigation as of treatments $\mathrm{T}_{12}-40$ lead to very high water productivity but yield quantity and quality decreased to be unacceptable. Similar results were reported by Ali et al. [25], Oweis and Hachum [26] and Zhang et al. [27]. Many explanations for the reason of increasing WP with DI, some of them are that the DI can increase the ratio of yield over crop water consumption (evapotranspiration) by the following: (1) reducing the water loss by unproductive evaporation, (2) increasing the proportion of marketable yield to the totally produced biomass (harvest index), (3) adequate fertilizer application and avoiding bad agronomic conditions during crop growth such as water logging in the root zone, pests and diseases, etc. (Geerts and Raes [28], Steduto and Albrizio [29], Pereira et al. [9]). 


\subsubsection{Greenhouse}

The T4-80 treatment was found to be the best treatment in terms of water productivity (Table 3); however the traditional irrigation led to lower water productivity $\left(19.7 \mathrm{~kg} \mathrm{~m}^{-3}\right)$. Moreover, decreasing irrigation water to $40 \% \mathrm{ET}$ caused very high water productivity; however, it decreased the final yield. Generally the crop water productivity (CWP) values increased when water amount decreased, the maximum value of CWP was $61.9 \mathrm{~kg} / \mathrm{m}^{3}$ for $\mathrm{T}_{12}-40$ treatment, and it was $42.3 \mathrm{~kg} / \mathrm{m}^{3}$ for full irrigation treatment (T1-100). Similar results were reported by Ali et al. [25], Oweis and Hachum [26] and Zhang et al. [27].

Table 2: $\quad$ Yield, evapotranspiration (ETc), applied water (AW), water useefficiency (WUE) and water productivity (WP) as affected by deficit irrigation treatments at different growth stages of cucumber planted in open field.

\begin{tabular}{|c|c|c|c|c|c|c|c|}
\hline Treatment & $\begin{array}{c}\text { Average } \\
\text { days } \\
\text { per } \\
\text { season }\end{array}$ & $\begin{array}{l}\text { Yield } \\
\operatorname{kg~m}_{2}^{-}\end{array}$ & $\begin{array}{l}\mathbf{E T}_{\mathbf{c}} \\
\mathbf{m m}\end{array}$ & $\begin{array}{l}\mathbf{A W} \\
\mathbf{m m}\end{array}$ & $\begin{array}{c}\mathrm{AW} \\
\mathbf{m m} \\
\text { day }^{-1}\end{array}$ & $\begin{array}{l}\text { WUE } \\
\underset{3}{\mathrm{~kg} \mathrm{~m}^{-}}\end{array}$ & $\begin{array}{c}\text { WP } \\
\mathrm{kg} \mathrm{m}_{3}^{-}\end{array}$ \\
\hline $\mathrm{T}_{1}-100$ & 91 & 7.2 & 617 & 727 & 8.0 & 11.7 & 9.9 \\
\hline $\mathrm{T}_{2}-80-0$ & 91 & 6.3 & 494 & 581 & 6.4 & 12.8 & 10.8 \\
\hline $\mathrm{T}_{3}-80-1$ & 91 & 6.2 & 520 & 611 & 6.7 & 11.9 & 10.1 \\
\hline $\mathrm{T}_{4}-80-2$ & 91 & 6.1 & 520 & 613 & 6.7 & 11.7 & 10.0 \\
\hline $\mathrm{T}_{5}-80-3$ & 91 & 6.5 & 538 & 631 & 6.9 & 12.1 & 10.3 \\
\hline $\mathrm{T}_{6}-80-4$ & 91 & 6.1 & 519 & 615 & 6.8 & 11.8 & 9.9 \\
\hline $\mathrm{T}_{7}-60-0$ & 91 & 4.9 & 370 & 436 & 4.8 & 13.2 & 11.2 \\
\hline $\mathrm{T}_{8}-60-1$ & 91 & 4.8 & 424 & 495 & 5.4 & 11.3 & 9.7 \\
\hline $\mathrm{T}_{9}-60-2$ & 91 & 5.2 & 424 & 500 & 5.5 & 12.3 & 10.4 \\
\hline $\mathrm{T}_{10-60-3}$ & 91 & 5.4 & 458 & 535 & 5.9 & 11.8 & 10.1 \\
\hline $\mathrm{T}_{11}-60-4$ & 91 & 4.9 & 420 & 504 & 5.5 & 11.7 & 9.7 \\
\hline $\mathrm{T}_{12-}-40-0$ & 91 & 3.4 & 223 & 267 & 2.9 & 15.2 & 12.7 \\
\hline $\begin{array}{c}\mathrm{T}_{13^{-}} \\
\text {Traditional }\end{array}$ & 91 & 5.8 & 617 & 1562 & 17.2 & 9.4 & 3.7 \\
\hline
\end{tabular}




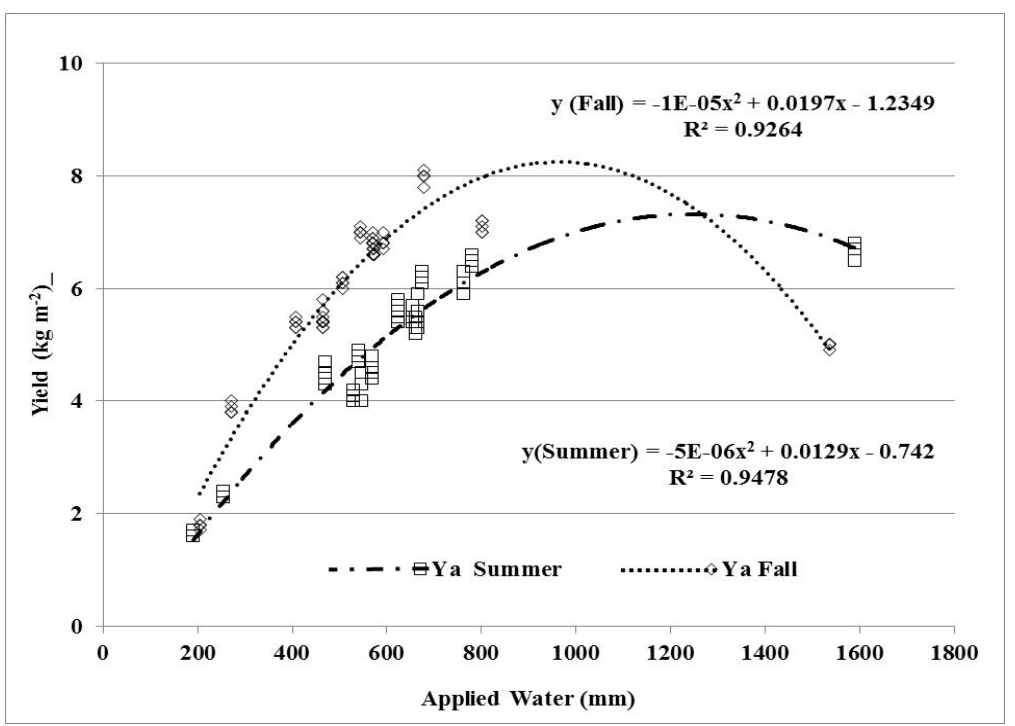

Figure 1: Yield as a function of applied water for two seasons of cucumber (open field).

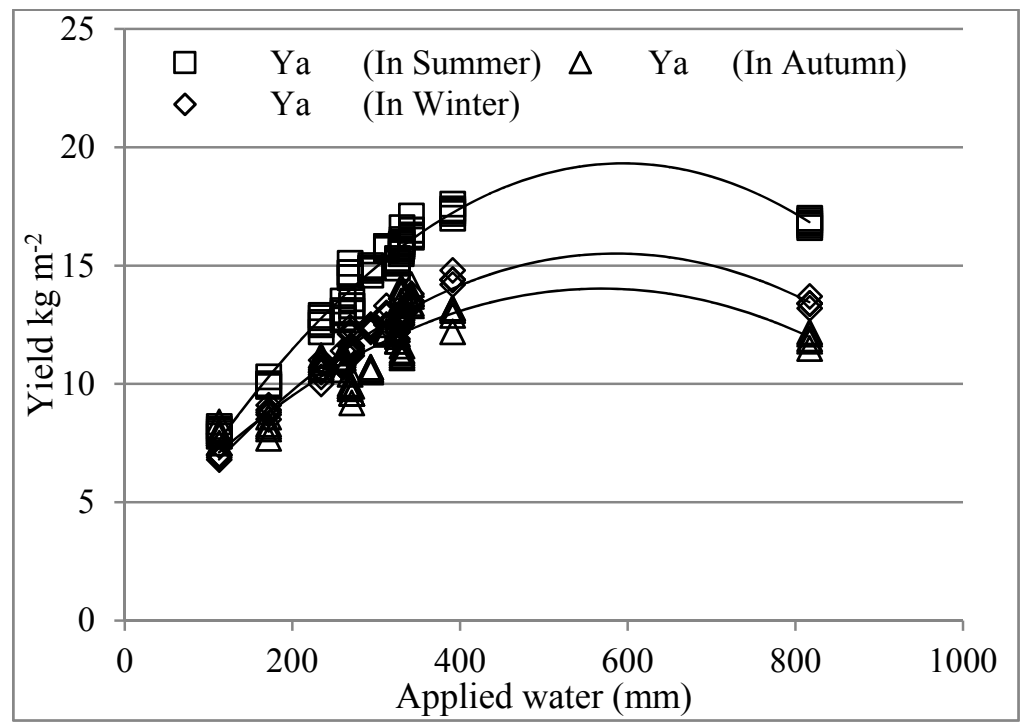

Figure 2: The relationship between marketable total cucumber yields planted on greenhouse and applied water at different seasons. 
Table 3: $\quad$ Mean yield, evapotranspiration (ETc), applied water (AW), and water productivity (WP) of different seasons as affected by deficit irrigation treatments at different growth stages of cucumber planted on greenhouse.

\begin{tabular}{|c|c|c|c|c|c|c|}
\hline Treatments & $\begin{array}{c}\text { Average } \\
\text { days per } \\
\text { season }\end{array}$ & $\begin{array}{c}\text { Yield } \\
\mathrm{kg} \mathrm{m}^{-2}\end{array}$ & $\begin{array}{c}\mathrm{ETc} \\
\mathrm{mm}\end{array}$ & $\begin{array}{c}\mathrm{AW} \\
\mathrm{mm}\end{array}$ & $\begin{array}{c}\mathrm{AW} \\
\mathrm{mm} \\
\mathrm{day}^{-1}\end{array}$ & $\begin{array}{c}\mathrm{CWP} \\
\mathrm{kg} \mathrm{m}^{-3}\end{array}$ \\
\hline $\mathrm{T}_{1}-100$ & 108 & $15.0 \mathrm{a}^{*}$ & 307 & 355 & 3.3 & 42.3 \\
\hline $\mathrm{T}_{2}-80-0$ & 108 & $13.8 \mathrm{bc}$ & 245 & 283 & 2.6 & 48.8 \\
\hline $\mathrm{T}_{3}-80-1$ & 108 & $13.2 \mathrm{~d}$ & 256 & 295 & 2.7 & 44.7 \\
\hline $\mathrm{T}_{4}-80-2$ & 108 & $14.2 \mathrm{~b}$ & 259 & 299 & 2.8 & 47.5 \\
\hline $\mathrm{T}_{5}-80-3$ & 108 & $14.6 \mathrm{ab}$ & 269 & 309 & 2.9 & 47.2 \\
\hline $\mathrm{T}_{6}-80-4$ & 108 & $13.5 \mathrm{~cd}$ & 260 & 300 & 2.8 & 45.0 \\
\hline $\mathrm{T}_{7}-60-0$ & 108 & $11.4 \mathrm{f}$ & 184 & 213 & 2.0 & 53.5 \\
\hline $\mathrm{T}_{8}-60-1$ & 108 & $11.7 \mathrm{f}$ & 204 & 236 & 2.2 & 49.6 \\
\hline $\mathrm{T}_{9}-60-2$ & 108 & $12.4 \mathrm{e}$ & 210 & 243 & 2.3 & 51.0 \\
\hline $\mathrm{T}_{10}-60-3$ & 108 & $12.7 \mathrm{e}$ & 232 & 267 & 2.5 & 47.6 \\
\hline $\mathrm{T}_{11}-60-4$ & 108 & $11.5 \mathrm{f}$ & 213 & 246 & 2.3 & 46.7 \\
\hline $\mathrm{T}_{12}-40$ & 108 & $9.1 \mathrm{~g}$ & 123 & 147 & 1.4 & 61.9 \\
\hline $\mathrm{T}_{13-}-\mathrm{Trad}$ & 108 & $14.2 \mathrm{~b}$ & 307 & 722 & 6.7 & 19.7 \\
\hline
\end{tabular}

*Treatment means with the same letter are not significant using LSD Test at 5\% level.

A polynomial function was fitted between (Y) and (AW) for different seasons (Fig. 2). According to the mathematical analysis of the crop water production function (CWPF), the predicted maximum yields were 19.49, 15.40, and 14.10 $\mathrm{kg} / \mathrm{m} 2$ and the corresponding calculated applied water was 600,582 , and $573 \mathrm{~mm}$ for summer, winter, and autumn respectively .These results were in agreement with those reported by Al-Harbi et al. [3] and Zhang and Oweis [24]. However, Mao et al. [13] reported a polynomial relationship between ET and yield. In this study, treatment T1-100 had the highest yield, treatments T3, 4, 5, 6-80 and T12-40 gave fairly good marketable yield while economically saving water, fertilizers and pesticide. The result also indicated that the CWP increased with decreasing amount of applied water; the CWP were 42.3 and $61.9 \mathrm{~kg} \mathrm{~m}^{-3}$ for T1-100 and T12-40 respectively. However the traditional irrigation treatment has the lowest value of WP $\left(19.7 \mathrm{~kg} \mathrm{~m}^{-3}\right)$. Although less irrigation, as in treatment T12-40, led to very high water productivity, it also led to poor quantity and quality of yield. 
The results also indicated that the deficit irrigation at $80 \%$ of ETc was more efficient in saving irrigation water with a good marketable yield compared to traditional irrigation and $100 \%$ ETc. Moreover the deficit drip irrigation helps in rationalization and preventing excessive use of pesticides and fertilizers consequently reducing and environmental pollution.

\subsubsection{Crop yield response factor}

The crop yield response factor (Ky) was determined for the different treatment of deficit irrigation. Ky indicates a linear relationship between the relative reduction in water consumed and relative reduction in yield (Lovelli et al. [17] and Kidra et al. [7]). Seasonal crop response factor Ky for different treatment through the open field growth were ranged between 0.96 to 1.02 for fall and summer respectively (Fig. 3). This means that cucumber (Cucumbissativus L.) grown in open field under Saudi Arabia arid conditions, cannot tolerate high severe water stress. These results were similar to those reported by Ayas and Demirta [16] who recorded a Ky value of 1.2 for cucumber (Cucumissativus L. Maraton) grown in Turkey. On the other hand, the Ky in greenhouse ranged between 0.57 and 0.76 for fall and winter respectively (Figure 3). This means that cucumber, grown in green house under Saudi Arabia arid conditions, can be considered as a water stress tolerant crop. These results were similar to those reported by Amer et al. [12].

\section{Conclusions}

The management of water under water scarcity includes multiple policies. In general, policies should aim to reduce the non-beneficial water uses, particularly those related to water consumption and to the non-reusable fraction of the diverted water. However, fully exploring these concepts, mainly for farmers at field scales, requires appropriate procedures to be developed. Reduced water demand can be achieved by adopting improved farm, irrigation systems, and deficit irrigation. In this study DI was tested for cucumber (Cucumbis sativus L.) in the green house and open field. It was found that full irrigation at the early and late stage and then irrigation with $80 \%$ of ETc was the best treatment in terms of water productivity and final yield; however decreasing irrigation water to $40 \%$ ETc caused very high water productivity while decreasing the final yield. Generally, under Saudi Arabian conditions, water use efficiency (WUE) and water productivity (WP) values increased when amount of applied water decreased. A polynomial relationship was determined between yield (Y) and applied water (AW) however, crop yield response factor $(\mathrm{Ky})$ indicated a linear relationship between the relative reduction in water consumed and relative reduction in yield with an average of 0.65 and 0.99 for greenhouse and open field, this means that cucumber can be considered as a water stress tolerant crop if planted under greenhouse ; on the other hand the cucumber will not tolerate high water stress at open field arid conditions. 

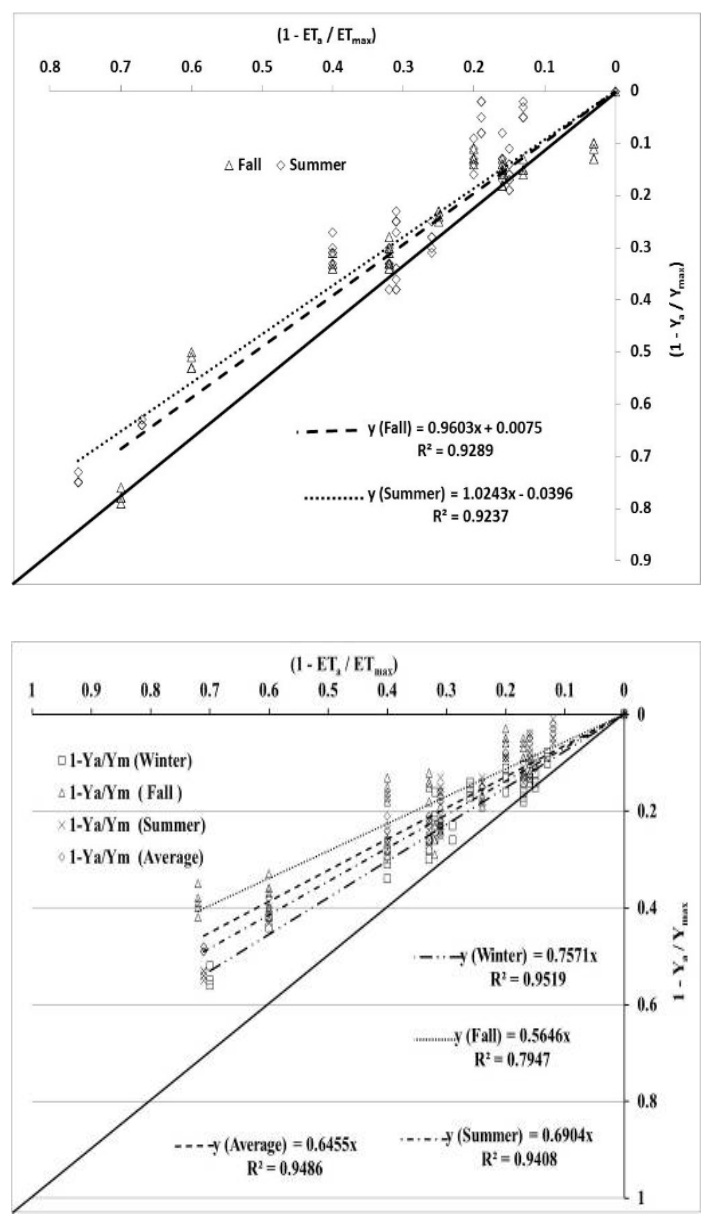

Figure 3: Relative cucumber yield decrease as function of relative evapotranspiration decrease.

\section{Acknowledgement}

The authors wish to thank King Saud University, Deanship of Scientific Research, College of Food and Agriculture Science, Research Center for supporting the research work.

\section{References}

[1] Bashour I. I., A.S. Al-Mashhady, J. Devi Prasad, T. Miller and M. Mazroa. Morphology and composition of some soils under cultivation in Saudi Arabia. Geoderma, 29(4): 327-340. 1983. 
[2] Al-Omran, A.M., A. S. Sheta, A. M. Falatah and A. R. Al-Harby, Effect of Drip Irrigation on Squash (Cucurbitapepo) Yields and Water Use Efficiency in Sandy Calcareous Soils Amended with Clay Deposits. Agricultural Water Management. 73(1): 43-55. 2005.

[3] Al-Harbi, A.R., Al-Omran, A.M., El-Adgham, F.I., Effect of drip Irrigation Levels and Emitters Depth on (Abelmoschusesculentus) Growth. J. of Applied Scie., 8, 2764-2769. 2008.

[4] Al-Omran, A.M., Al-Harbi, A. R.,Wahb-Allah, M. A., Nadeem, M., Eleter, A, Impact of irrigation water quality, irrigation systems, irrigation rates and soil amendments on tomato production in sandy calcareous soil. Turk J. Agric. For. 34, 59-73. 2010.

[5] Topcu, S., Kirda, C., Dasgan, Y., Kaman, H., Cetin, M., Yazici, A., Bacon, M.A. Yield response and $\mathrm{N}$-fertiliser recovery of tomato grown under deficitirrigation. European Journal of Agronomy. 26, 64-70. 2007.

[6] Patanè, C., Cosentino, S.L., Effects of soil water deficit on yield and quality of processing tomato under a Mediterranean climate. Agricultural Water Management, 97(1), 131-138. 2009.

[7] Kirda, C., M. Cetin, Y. Dasgan, S. Topcu, H. Kaman, B. Ekici, M. R. Derici, Ozguven, A. I., Yield response of greenhouse grown tomato to partial root drying and conventional deficit irrigation. Agricultural Water Management. 69(3), 191-201. 2004.

[8] Sepaskhah, A.R., Akbari, D., Deficit irrigation planning under variable seasonal rainfall. Biosyst. Eng. 92, 97-106. 2005.

[9] Pereira, L.S., Oweis, T., Zairi, A., Irrigation management under water scarcity. Agric. Water Manage 57, 175-206. 2002.

[10] Zegbe-Domìnguez, J.A., Behboudian, M.H., Lang, A., Clothier, B.E., Deficitirrigation and partial rootzone drying maintain fruit dry mass and enhance fruit quality in 'Petopride' processing tomato (Lycopersicone sculentum Mill.), Scientia Horticulturae 98, 505-510. 2003.

[11] Agele, S.O., Iremiren, G.O., Ojeniyi, S.O., Evapotranspiration, water use efficiency and yield of rainfed and irrigated tomato. Int. J. Agric. Biol. 13, 469-476. 2011.

[12] Amer, K. H, Sally, A. M., Jerry, L. H., Effect of Deficit Irrigation and Fertilization on Cucumber. Agronomy Journal. 101, 1556-1564. 2009.

[13] Mao, X., Liu, M, Wang, X., Hou, C., Z., Shi, J., Effects of deficit irrigation on yield and water use of greenhouse grown cucumber in the North China Plain. Agricultural water management. 61(3), 219-228. Doi: 10.1016/ S0378-3774(03)00022-2. 2003.

[14] Kirda, C., Deficit irrigation scheduling based on plant growth stages showing water stress tolerance. In Deficit irrigation practices. C. Kirda, P. Moutonnet, C. Hera and D.R. Nielsen (eds). Water Report \#22 FAO, Rome. 2000.

[15] Moutonnet, P., Yield Response to Field Crops to Deficit Irrigation in Deficit irrigation practices. C. Kirda, P. Moutonnet, C. Hera and D.R. Nielsen (eds).Water Report \#22 FAO, Rome. 2000. 
[16] Ayas, S., Demirta, C., Deficit irrigation effects on cucumber (Cucumissativus L. Maraton) yield in unheated greenhouse condition. Inter. J. of food, agric. and enviro. 7, 645-649. 2009.

[17] Lovelli, S., Perniola, M, Ferrara, A., Tammaso. T. D., Yield response factor to water (Ky) and water use efficiency of Carthamustinctorius L. and Solaummelongeual. Agric. Water Management, 92, 73-80. 2007.

[18] Page, A.L., Miller, R.b., Keeney, D.R., Methods of soil analysis part 2. Chemical and microbiological properties. Second Edition. 1982.

[19] Richards, L.A. (ed.), Diagnosis and improvement of saline and alkaline soils. USDA Handbook No. 60. 1954.

[20] Simsek, M., Tonkaz, T., Kacira, M., Comlekcioglu, N., Dogan, Z., The Effects of Different Irrigation Regimes on Cucumber (Cucumbissativus L.) Yield and Yield Characteristics under Open Field Conditions. Agricultural Water Management, 73(3), 173-191. 2005.

[21] Allen, R.G., Pereira, L.S., Raes, D., Smith, M, 1998. Crop evapotranspiration guidelines for computing crop water requirements. FAO Irrigation and Drainage paper \#56.

[22] Molden, D., Comprehensive assessment of water management in agriculture series, International water management Institute Pelawata, Battarnulla, Sri Lanka. 2003.

[23] Doorenbos, J., Kassam, A. H., Yield response to water. FAO Irrigation and Drainage Paper No. 33, FAO, Rome, Italy. 193, 1986.

[24] Zhang, H., Oweis, T., Water-yield relations and optimal irrigation scheduling of wheat in the Mediterranean region. Agricultural Water Management. 38, 195-211. 1999.

[25] Ali, M.A., Hoque, M.R., Hassan, A.A., Khair, A., Effects of deficit irrigation on yield, water productivity, and economic. Agric. Water Management. 92, 151-161. Doi: 10.1016/j.agwat.2007.05.010. 2007.

[26] Oweis, T., Hachum, A., Water harvesting and supplemental irrigation for improved water productivity of dry farming system in west Asia and North Africa. In Proceeding of the $4^{\text {th }}$ Int. Crop Sci. Congress, held at Brisbane, on the theme "Crop Science for Diversified planet". 2004.

[27] Zhang, Y., Kendy, E., Qiang, Y., Changming, L., Yanjun, S., Hong yong, S., Effect of soil water deficit on evapotranspiration, crop yield, and water use efficiency in the North China Plain. Agric. Water Management. 64, 107-122. 2004.

[28] Geerts, S., Raes, D., Deficit irrigation as an on-farm strategy to maximize crop water productivity in dry areas. Agric. Water Management. 96, 1275-1284. 2009.

[29] Steduto, P., Albrizio, R., Resource use efficiency of field-grown sunflower, sorghum, wheat and chickpea. II. Water use efficiency and comparison with radiation use efficiency. Agric. Forest Meteorol. 130, 269-281. 2005. 